reported an E. coli strain with a loop of DNA containing a single unnatural base pair (D. A. Malyshev et al. Nature 509, 385-388; 2014). But the cells divided sluggishly, and tended to lose their foreign DNA over time. In the latest research, the team created healthy cells with extra bases made of chemicals called dNaM and dTPT3 (dubbed X and Y, respectively).

And they can finally wield their foreign DNA. In separate experiments, the cells incorporated two unnatural amino acids (called PrK and $\mathrm{pAzF}$ ) into a protein that emits a soft, green glow (see 'A foreign language'). Both the foreign bases and the amino acids were fed to the cells, and any organism that somehow escaped the lab would not be able to produce them. To allow the cells to use these components, the researchers created modified versions of molecules called tRNAs, which read codons and ferry the appropriate amino acids to the cells' protein factories - ribosomes.

The new amino acids did not change the shape or function of the green fluorescent protein. But "now that we can store and retrieve information", says Romesberg, "let's do something with it". In unpublished work, his team has inserted a foreign base pair into a key site in the gene implicated in antibiotic resistance. Bacteria that shed their foreign DNA become sensitive to penicillin-related drugs.

Romesberg has started a biotechnology company, Synthorx in La Jolla, which is attempting to incorporate unnatural amino acids into protein-based drugs such as IL-2, which regulates numbers of white blood cells. The approach could lead to drugs that, for example, are taken up by cells more easily, or that are less toxic or break down more quickly. Proteins could also be

\title{
A FOREIGN LANGUAGE
}

Researchers added a synthetic base pair (nicknamed $X$ and $Y$; shown in blue) to DNA to encode new amino acids, which cells then incorporated into the fluorescent protein GFP.

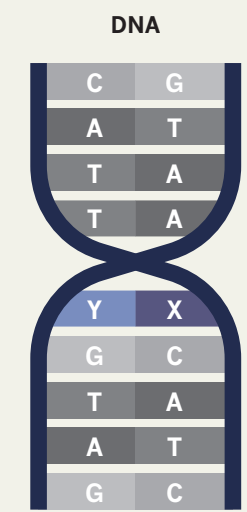

Six nucleotides Three base pairs
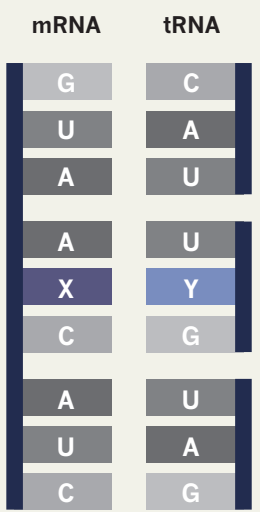

216 possible codons could code for up to 172 amino acids

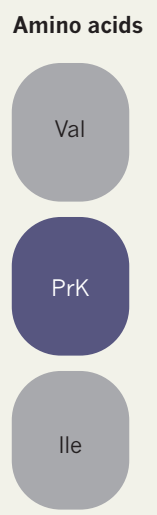

Green fluorescent protein

designed to have properties that conventional amino acids lack, such as the ability to strongly attract electrons. "It's like being a kid in a candy store," says Romesberg. But in this case, "the kid spent 20 years fantasizing about getting into that candy store. All of sudden I'm thinking what kind of candy can I get."

Teams led by chemist Steven Benner of the Foundation for Applied Molecular Evolution near Gainesville, Florida, and Ichiro Hirao, a biological chemist at the Institute of Bioengineering and Nanotechnology in Singapore, have already developed test-tube systems for using foreign DNA to encode unnatural amino acids. Hirao sees advantages to moving into living cells. Proteins containing unnatural amino acids could be made more quickly and cheaply using bacterial cells, he says. Bringing the technology to eukaryotic cells would allow development of new antibody-based drugs, too.

But Benner suggests that because Romesberg's system relies on relatively weak hydrophobic forces to hold foreign base pairs together, its potential for industrial applications might be limited. Cells may tolerate the rare foreign base, Benner says, but "one simply cannot build an entire genetic system from them".

Romesberg and his colleagues are now working on expanding their genetic alphabet further. So far, the team has identified 12 more codons containing X and $\mathrm{Y}$ that are functional, says Romesberg, but "there's a lot yet to do".

\section{Britain pins economic hopes on science}

\author{
Industrial strategy splashes cash on research.
}

\section{BY ELIZABETH GIBNEY}

$\mathrm{T}$ The United Kingdom has laid out how it will pour money into research to boost its economy - including cash for artificial intelligence and other high-tech industries - as the country prepares to leave the European Union in 2019.

Science does not usually sit at the forefront of British economic-policy documents. But the UK government's new industrial strategy, released on 27 November, is sprinkled throughout with references to research and development (R\&D), highlighting a focus on research as a remedy for economic woes. "It feels like science permeates this strategy," says Graeme Reid, a science-policy researcher at University College London.

The shift in emphasis will change expectations, says Paul Nightingale, deputy director of the Science Policy Research Unit at the University of Sussex in Brighton, UK. Historically, commercializing research has not been seen as a strength of the UK universities system. But in return for $\mathrm{R} \& \mathrm{D}$ cash, universities will now be expected to increase their commercial focus and interaction with local businesses, he says: “This isn't 'strings attached', this is ropes. My impression from talking to lots of academics is that they don't understand how big this is."

The industrial strategy is an effort to boost UK productivity - economic output per hour worked - which has stagnated since the financial crisis and lags behind that of other industrialized nations. In part to counter that trend, the government has promised to massively boost R\&D spending: from $1.7 \%$ of gross domestic product (GDP) in 2015 to $2.4 \%$ by 2027 . (By comparison, Germany already spends $2.9 \%$ of GDP on research; the United States, 2.8\%).

UK scientists have already been promised boosts in public spending. Last year, politicians committed to yearly increases in research funding until 2020-21; last week, they announced that they would continue that increase in 2021-22, raising public research funds by a further $£ 500$ million (US $\$ 667$ million), to $£ 12.5$ billion. To raise private spending, the government promises to work with industry to produce a road map in the coming months; UK chancellor Philip Hammond 
- announced a rise in $\mathrm{R} \& \mathrm{D}$ tax credits (from $11 \%$ to $12 \%$ ) in the budget.

The industrial strategy picks out specific areas on which to splash the cash. In particular, it identifies four 'grand challenges' in hightech fields: artificial intelligence (AI) and big data; clean growth; the future of mobility; and meeting the needs of an ageing society. These areas will benefit from an additional $£ 725$ million over the next 4 years from the Industrial Strategy Challenge Fund (ISCF) - a cash pot that has allocated $£ 1$ billion since its launch last year. Meanwhile, $£ 45$ million will be spent to support more $\mathrm{PhD}$ students in $\mathrm{AI}$ and related disciplines, increasing numbers by at least 200 places a year by $2020-21$.

Other measures likely to directly affect academic scientists include a promised boost to a stream of funding that is allocated directly to universities, and spent at their discretion. This funding is crucial for blue-skies and basic research, but has remained largely unchanged since 2010. An unspecified fund is also promised to support multi- and interdisciplinary research: an idea proposed in a 2015 review by Nobel laureate Paul Nurse.

The strategy mentions a plethora of technology-based schemes, including unspecified 'sector deals' with industry to drive productivity in areas such as the life sciences. It is likely that the government will not have enough capacity to manage them all internally, says Kieron Flanagan, a science-policy researcher at the Alliance Manchester Business School, UK. Flanagan thinks this will ultimately put greater responsibility into the hands of UK Research and Innovation (UKRI), an organization that from 2018 will consolidate the activities of nine existing UK funding agencies. If the organization ends up steering the direction of more industrial R\&D, "it makes UKRI a uniquely powerful beast”, he says.

\section{China to ease regulations on traditional medicine}

\section{Scientists fear plans to abandon clinical trials of ancient remedies will put people at risk.}

\section{BY DAVID CYRANOSKI}

S upport for traditional medicine in China goes right to the top. President Xi Jinping has called this type of medicine a "gem" of the country's scientific heritage, and promised to give alternative therapies and Western drugs equal government support. Now the country is taking dramatic steps to promote these cures even as researchers raise concerns about such treatments.

From early next year, traditional Chinese medicines (TCMs) may no longer be required to pass safety and efficacy trials in humans in China. Draft regulations announced in October by the China Food and Drug Administration (CFDA) mean traditional medicines can skip such costly and time-consuming trials as long as manufacturers prepare ingredients using essentially the same method as in classic Chinese formulations. The State Administration of Traditional Chinese Medicine and the CFDA will compose a list of the approved methods.

The Chinese government has been forcefully promoting TCMs as an alternative to expensive Western drugs. Doctors of Chinese medicine have welcomed the new policy, saying that it will make it easier for companies that produce such medicines to get drugs approved and make them available to patients. Lixing Lao, director of Hong

"Few doctors would dare to publicly criticize traditional Chinese medicines." Kong University's School of Chinese Medicine, says that although traditional medicines will no longer need to go through clinical trials, the CFDA will still require remedies to undergo preclinical pharmacological testing and drug-toxicity studies in animals or cells to gain approval.

But scientists say that safety concerns continue to plague the industry, and that minimizing clinical-trial requirements could put more people at risk. On 23 September, the CFDA recalled batches of two injectable
TCMs after about ten people fell ill with fevers and chills.

Less than a month later, on 18 October, researchers in Singapore and Taiwan published a study in Science Translational Medicine linking liver cancer to aristolochic acid, an ingredient widely used in traditional remedies ${ }^{1}$. Lead author Steven Rozen, a cancer-genomics researcher at Duke-NUS Medical School in Singapore, is convinced that aristolochic acid contributed to the mutations in the cancer cells, but says it's harder to determine to what extent it caused the tumours.

Aristolochic acid has also been linked to cancers of the urinary tract and can cause fatal kidney damage ${ }^{2,3}$. Rozen says that it is still in common use, despite warnings from the US Food and Drug Administration that it is associated with kidney disease. "It would be a good time to reassess regulations" of aristolochic acid, he says.

Lao sees people take remedies containing aristolochic acid every day, and says it should not cause problems if taken "moderately and

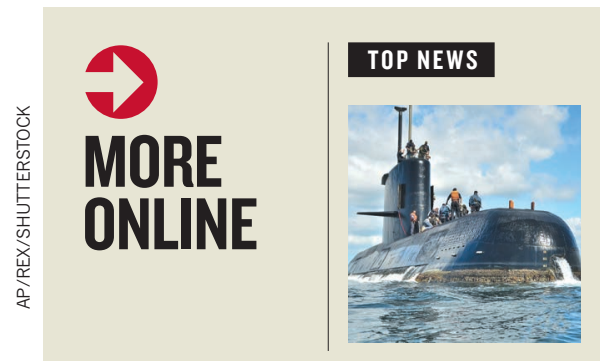

How ocean sensors are tracking Argentina's lost submarine go.nature. com/2nalhcl

\section{MORE NEWS}

- Zimbabwe's researchers hope political change will revitalize science go.nature.com/2nfebyk

- Lightning makes new isotopes go.nature.com/2btkjjz

- How alkali flies stay dry

go.nature.com/2jsuwbb

\section{NATURE PODCAST}

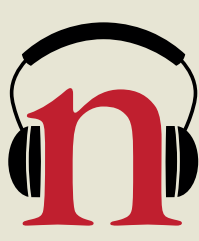

Reading unnatural DNA, and young worm mothers explain a wriggly riddle nature.com/nature/ podcast 